\title{
Conservation Agriculture: Concepts, Brief History, and Impacts on Agricultural Systems
}

Chapter · January 2015

DOI: 10.1007/978-3-319-11620-4_1

CITATIONS

3

2 authors:

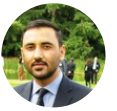

Muhammad Farooq

Hohenheim University

267 PUBLICATIONS $\quad \mathbf{4 , 6 1 8}$ CITATIONS

SEE PROFILE
READS

614
Kadambot H M Siddique

University of Western Australia

383 PUBLICATIONS $\quad 7,759$ CITATIONS

SEE PROFILE 


\title{
Chapter 1 \\ Conservation Agriculture: Concepts, Brief History, and Impacts on Agricultural Systems
}

\author{
Muhammad Farooq and Kadambot H. M. Siddique
}

\begin{abstract}
Conservation agriculture (CA) is characterized by minimal soil disturbance, diversified crop rotations, and surface crop residue retention to reduce soil and environmental degradation while sustaining crop production. CA involves changing many conventional farming practices as well as the mindset of farmers to overcome the conventional use of tillage operations. Although adoption of CA is increasing globally, in some regions it is either slow or nonexistent. The adoption of CA has both agricultural and environmental benefits but there is a lack of information on the effects and interactions of key CA components which affect yield and hinder its adoption. In this chapter, we discuss the basic concepts and brief history of CA, and its impacts on agricultural systems.
\end{abstract}

Keyword Adoption - Crop rotations $\cdot$ Crop residues $\cdot$ Farm machinery $\cdot$ Weed management

\subsection{Introduction}

Conventional farming practices, in particular tillage and crop residue burning, have substantially degraded the soil resource base (Montgomery 2007; Farooq et al. 2011a), with a concomitant reduction in crop production capacity (World Resources Institute 2000). Under conventional farming practices, continued loss of soil is expected to become critical for global agricultural production (Farooq et al. 2011a).

M. Farooq $(\square)$

Department of Agronomy, University of Agriculture, Faisalabad, Pakistan

e-mail: farooqcp@gmail.com

The UWA Institute of Agriculture, The University of Western Australia,

Crawley, WA 6009, Australia

College of Food and Agricultural Sciences, King Saud University, Riyadh 11451, Saudi Arabia

M. Farooq · K. H. M. Siddique

The UWA Institute of Agriculture, The University of Western Australia, Crawley, WA 6009, Australia 
Fig. 1.1 Elements of conservation agriculture

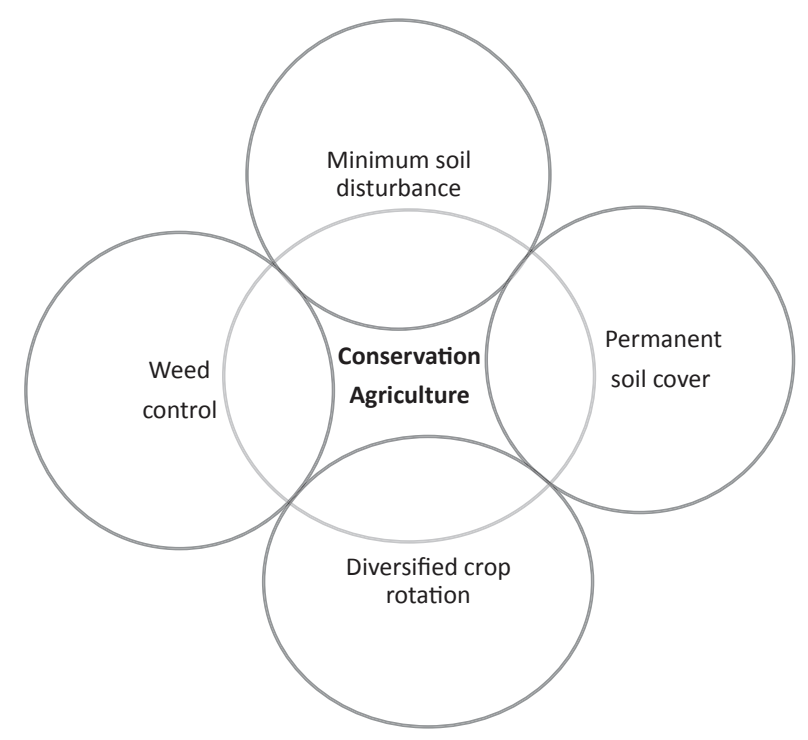

Conservation agriculture (CA) is a set of technologies, including minimum soil disturbance, permanent soil cover, diversified crop rotations, and integrated weed management (Fig. 1.1; Reicosky and Saxton 2007; Hobbs et al. 2008; Friedrich et al. 2012), aimed at reducing and/or reverting many negative effects of conventional farming practices such as soil erosion (Putte et al. 2010), soil organic matter (SOM) decline, water loss, soil physical degradation, and fuel use (Baker et al. 2002; FAO 2008). For instance, soil erosion, water losses from runoff, and soil physical degradation may be minimized by reducing soil disturbance and maintaining soil cover (Serraj and Siddique 2012). Using organic materials as soil cover and including legumes in rotations may help to address the decline in SOM and fertility (Marongwe et al. 2011). With less soil disturbance comes less fuel use, resulting in lower carbon dioxide emissions, one of the gases responsible for global warming (Kern and Johnson 1993; West and Marland 2002; Hobbs and Gupta 2004; Holland 2004; Govaerts et al. 2009). CA helps to improve biodiversity in the natural and agro-ecosystems (Friedrich et al. 2012). Complemented by other good agricultural practices, including the use of quality seeds and integrated pest, nutrient and water management, etc., CA provides a base for sustainable agricultural production intensification (Friedrich et al. 2012). Moreover, yield levels in CA systems are comparable and even higher than traditional intensive tillage systems (Farooq et al. 2011a; Friedrich et al. 2012) with substantially less production costs (Table 1.1).

CA is increasingly promoted as "a concept of crop production to a high and sustained production level to achieve acceptable profit, while saving the resources along with conserving the environment" (FAO 2006). In CA, modern and scientific agricultural technologies are applied to improve crop production by mitigating reductions in soil fertility, topsoil erosion and runoff; and improving moisture conservation and environmental footprints (Dumanski et al. 2006). CA improves soil 
Table 1.1 Cost comparison of traditional (TA) and conservation agriculture (CA). (Source: Data from Hanks and Martin (2007); Meena et al. (2010); Singh and Meena (2013)

\begin{tabular}{l|c|l|l}
\hline & TA $\left(\mathrm{USD} \mathrm{ha}^{-1}\right)$ & $\mathrm{CA}\left(\mathrm{USD} \mathrm{ha}^{-1}\right)$ & Cost saving (\%) \\
\hline Fuel & 75 & 25 & 66.67 \\
\hline Depreciation & 115 & 65 & 43.47 \\
\hline Maintenance & 22 & 10 & 54.55 \\
\hline Pesticides & 35 & 45 & -28.57 \\
\hline Total costs & 247 & 145 & 41.30 \\
\hline
\end{tabular}

water-use efficiency, enhances water infiltration, and increases insurance against drought (Colmenero et al. 2013). CA is thus an eco-friendly and sustainable management system for crop production (Hobbs et al. 2008; Govaerts et al. 2009) with potential for all agroecological systems and farm sizes. This chapter provides a brief history and overview of the components and adaptation of CA.

\subsection{History and Adoption of Conservation Agriculture}

Tillage is defined as the mechanical manipulation of soil. Tillage started millions of years ago when man shifted from hunting to more sedentary and conventional agriculture especially in the Euphrates, Nile, Tigris, Yangste, and Indus valley (Hillel 1991). The idea to plough or till the soil began in Mesopotamia around 3000 BC (Hillel 1998). Lal (2001) identified tillage as a major component of husbandry practices in agriculture. After the industrial revolution in the nineteenth century, agricultural machinery became available to carry tillage operations. More recently, a range of equipment has become available for tillage operations in agricultural production (Hobbs et al. 2008). Traditionally, tillage was aimed to soften the soil, prepare the seedbed to ensure good and uniform seed germination, manage weeds, help in the release of soil nutrients needed for crop growth through mineralization and oxidation, and incorporate crop residues and soil amendments (fertilizers, organic or inorganic) into the soil (Hobbs et al. 2008). Moreover, tillage helps to modify soil's physical, chemical, and biological properties, which improves conditions for crop growth resulting in higher crop yields (Farooq et al. 2011a).

Tillage, particularly in fragile ecosystems, was questioned for the first time in the 1930s by Edward H. Faulkner, in a manuscript called "Plowman's Folly" (Faulkner 1943) when dust bowls devastated wide areas of the Midwestern USA (Friedrich et al. 2012). With time, the concept of protecting soil, by reducing tillage and keeping the soil covered, gained popularity. This system of soil protection was then named conservation tillage (Friedrich et al. 2012). Economic and ecological sufferings caused by disastrous droughts in the USA during the 1930s drove the shift towards CA (Haggblade and Tembo 2003). The development of seeding machinery during the 1940s made sowing possible without soil tillage (Friedrich et al. 2012). Moreover, increased fuel prices during the 1970s attracted farmers to shift towards resource-saving farming systems (Haggblade and Tembo 2003). In this scenario, commercial farmers adapted CA to combat drought-induced soil erosion together with the fuel saving (Haggblade and Tembo 2003). 
During the early 1970s, no-tillage farming reached Brazil; and no-tillage and mulching were tested in West Africa (Table 1.2; Greenland 1975; Lal 1976). The CA experience in the USA helped motivate the CA movement in South Africa and South America (Haggblade and Tembo 2003). Nonetheless, CA took more than 20 years to reach significant adoption levels in South America (Friedrich et al. 2012). During this time, farm equipment and agronomic practices in no-tillage systems were improved and developed to optimize crop performance and machinery, and field operations (Friedrich et al. 2012).

In the early 1990s, the spread of CA hastened, which revolutionized farming systems in Argentina, southern Brazil, and Paraguay (Friedrich et al. 2012). During this time, several international organizations became interested in the promotion of CA. Participation of these organizations in the promotion of these conservation farming systems led to the adoption of these systems in Africa (Tanzania, Zambia, and Kenya) and some parts of Asia (Kazakhstan, China, India, and Pakistan). CA systems then made their way to Canada, Australia, Spain, and Finland.

Today, CA is practiced on millions of hectares across the globe (FAO 2011a) including the USA, Argentina, Bolivia, Brazil, Chile, China, Colombia, Falkland Islands, Finland, Kazakhstan, Kenya, Malvinas, Morocco, Uganda, Western Australia, and Zambia (Friedrich et al. 2012) on soils varying from $90 \%$ sand (e.g., Australia) to $80 \%$ clay (e.g., Brazil's Oxisols and Alfisols). Derpsch and Friedrich (2009) reported that any crop can be grown effectively under CA including tuber and root crops. In recent years, the spread of CA has been quite rapid. In 19731974, CA was practiced on $2.8 \mathrm{M}$ ha globally, increasing to $6.2 \mathrm{M}$ ha in a decade; by $1996-1997$, this area had reached $38 \mathrm{M}$ ha, and by 2003 , it was $72 \mathrm{M}$ ha. More recently, CA has been practiced on $125 \mathrm{M}$ ha (Friedrich et al. 2012).

CA has positive effects in terms of yield, income, sustainability of land use, ease of farming, and the timeliness of ecosystem services and cropping practices. As a result, its adoption rate has increased by $7 \mathrm{M}$ ha per year in the past decade (Friedrich et al. 2012). Of the total area under CA systems worldwide, $45 \%$ is in South America, 32\% in USA and Canada, 14\% in Australia and New Zealand, and $9 \%$ in the rest of the world including Asia, Europe, and Africa (Table 1.3; Friedrich et al. 2012). In Canada, CA adoption has seen a pragmatic eco-friendly approach as that helped to decrease the dust storms and increase the biodiversity (Lindwall and Sonntag 2010). Carbon payment schemes have been introduced in Alberta and Canada, which have resulted in the rapid uptake of CA in these areas (Friedrich et al. 2012).

Despite the continued effort of international organizations and local NGOs, the total area under CA is only $9 \%$ of the total cropped area (Friedrich et al. 2012). A lack of CA extension programs is one reason for its slow uptake. In addition, regional traditions and mindset, along with a lack of technical knowledge, institutional support, CA machinery, and suitable herbicides to facilitate weed management are major constraints in the wide-scale adoption of CA systems (FAO 2008; Friedrich and Kassam 2009; Friedrich et al. 2012). Certain other issues related to natural assets of the farm also hinder CA adoption worldwide (Dixon et al. 2001; Govaerts et al. 2009). However, in Asia, many agricultural lands may adopt CA systems 
1 Conservation Agriculture: Concepts, Brief History, and Impacts ...

Table 1.2 History of conservation agriculture

\begin{tabular}{|c|c|c|}
\hline Year & Development & Reference \\
\hline 1930 & $\begin{array}{l}\text { Great dust bowl and start of conservation agricul- } \\
\text { ture in the USA }\end{array}$ & Hobbs et al. (2008) \\
\hline 1940 & $\begin{array}{l}\text { Development of direct seeding machinery, first } \\
\text { no-till sowing }\end{array}$ & Friedrich et al. (2012) \\
\hline 1943 & $\begin{array}{l}\text { Book on no-till in modern agriculture entitled } \\
\text { "Plowman's Folly" by Faulkner }\end{array}$ & Faulkner (1943) \\
\hline 1950 & $\begin{array}{l}\text { No-till, direct-sowing of crops was first success- } \\
\text { fully demonstrated in the USA }\end{array}$ & Harrington (2008) \\
\hline 1956 & $\begin{array}{l}\text { Experiments on various combinations of tillage and } \\
\text { herbicides were initiated }\end{array}$ & Lindwall and Sonntag (2010) \\
\hline 1960 & Commercial adoption of no-till in the USA & $\begin{array}{l}\text { Lindwall and Sonntag (2010); } \\
\text { Friedrich et al. (2012) }\end{array}$ \\
\hline 1962 & $\begin{array}{l}\text { Paraquat was registered as first herbicide for broad- } \\
\text { spectrum weed control }\end{array}$ & Lindwall and Sonntag (2010) \\
\hline 1962 & $\begin{array}{l}\text { Long-term no-till experiments were started in Ohio, } \\
\text { USA; the experiments are still running }\end{array}$ & Perszewski (2005) \\
\hline 1964 & First no-till experiments in Australia & Barret et al. (1972) \\
\hline 1966 & $\begin{array}{l}\text { Demonstration trials on direct drilling systems in } \\
\text { Germany }\end{array}$ & Bäumer (1970) \\
\hline 1967 & $\begin{array}{l}\text { Demonstration trials on direct drilling systems in } \\
\text { Belgium }\end{array}$ & Cannel and Hawes (1994) \\
\hline 1968 & First no-tillage trials in Italy & Sartori and Peruzzi (1994) \\
\hline 1969 & Introduction of CA in West Africa & Greenland (1975); Lal (1976) \\
\hline 1970 & First no-till demonstration in Brazil & Borges (1993) \\
\hline 1970 & $\begin{array}{l}\text { Long-term no-till experiments were started in } \\
\text { France }\end{array}$ & Boisgontier et al. (1994) \\
\hline 1970 & $\begin{array}{l}\text { First report on the development of herbicide resis- } \\
\text { tance in weeds }\end{array}$ & Ryan (1970) \\
\hline 1973 & $\begin{array}{l}\text { Phillips and Young published the book "No-Tillage } \\
\text { Farming." This publication was a milestone in } \\
\text { no-tillage literature, being the first one of its kind in } \\
\text { the world }\end{array}$ & Derpsch (2007) \\
\hline 1974 & First no-till demonstration in Brazil and Argentina & Friedrich et al. (2012) \\
\hline 1975 & $\begin{array}{l}\text { Book on CA entitled “One straw revolution” by } \\
\text { Fukuoka }\end{array}$ & Fukuoka (1975) \\
\hline 1976 & $\begin{array}{l}\text { Glyphosate was registered for general broad-spec- } \\
\text { trum weed control }\end{array}$ & Lindwall and Sonntag (2010) \\
\hline 1980 & $\begin{array}{l}\text { Introduction and on-farm demonstration of CA in } \\
\text { subcontinent }\end{array}$ & Harrington (2008) \\
\hline 1980 & Introduction of CA in Zimbabwe & Friedrich et al. (2012) \\
\hline 1981 & $\begin{array}{l}\text { The first National No-till Conference held in Ponta } \\
\text { Grossa, Paraná, Brazil }\end{array}$ & Derpsch (2007) \\
\hline 1982 & Introduction of no-till in Spain & Giráldez and González (1994) \\
\hline 1982 & $\begin{array}{l}\text { Development of first glyphosate-resistant transgenic } \\
\text { crops }\end{array}$ & Fraley et al. (1983) \\
\hline 1990 & $\begin{array}{l}\text { Development and commercial release of reliable } \\
\text { seeding machines }\end{array}$ & Lindwall and Sonntag (2010) \\
\hline 1990 & $\begin{array}{l}\text { Commercial adaptation of CA in southern Brazil, } \\
\text { Argentina, and Paraguay }\end{array}$ & Friedrich et al. (2012) \\
\hline 1990 & $\begin{array}{l}\text { Introduction of CA in India, Pakistan, and } \\
\text { Bangladesh }\end{array}$ & Friedrich et al. (2012) \\
\hline
\end{tabular}


Table 1.2 (continued)

\begin{tabular}{l|l|l}
\hline Year & Development & Reference \\
\hline 1992 & Start of CA research in China & Derpsch and Friedrich (2009) \\
\hline 1996 & $\begin{array}{l}\text { Commercial launch of transgenic glyphosate-resis- } \\
\text { tant soybean }\end{array}$ & Dill (2005) \\
\hline 1997 & $\begin{array}{l}\text { Commercial launch of transgenic glyphosate-resis- } \\
\text { tant crops in China }\end{array}$ & Paarlberg (2001) \\
\hline 1998 & $\begin{array}{l}\text { Identification of weed (rigid ryegrass) resistant to } \\
\text { glyphosate }\end{array}$ & Powles et al. (1998) \\
\hline 2002 & Introduced no-tillage systems in Kazakhstan & Derpsch and Friedrich (2009) \\
\hline
\end{tabular}

$C A$ conservation agriculture

Table 1.3 Continent-wise area under conservation agriculture in the world. (Source: Friedrich et al. 2012)

\begin{tabular}{l|c|c}
\hline Continent & Area $(\mathrm{M} \mathrm{ha})$ & Percent of total \\
\hline Africa & 1.01 & 1 \\
\hline Asia & 4.72 & 4 \\
\hline Australia and New Zealand & 17.16 & 14 \\
\hline Europe & 1.35 & 1 \\
\hline South America & 55.46 & 45 \\
\hline North America & 39.98 & 32 \\
\hline Russia and Ukraine & 5.1 & 3 \\
\hline Total & 124.78 &
\end{tabular}

especially in Kazakhstan, China, and India in the next two decades (Friedrich et al. 2012). In the Indo-Gangetic Plains (Pakistan, India, Bangladesh, and Nepal), notilled wheat plantations have reached $5 \mathrm{M}$ ha in recent years especially in the ricewheat cropping system (Friedrich et al. 2012) and are expected to expand further.

In a nutshell, since the 1930 s, farming communities have gradually shifted towards no-tillage systems for potential fossil-fuel savings, reduced erosion, and runoff, and to minimize SOM loss. The first 50 years was the start of the conservation tillage movement and, today, a large percentage of agricultural land is cropped following CA principles (Hobbs et al. 2008). Sustained governmental policies and institutional support may play a key role in the promotion of CA both in rainfed and irrigated cropped lands by providing incentives and required services to farmers to adopt CA practices and advance them over time (FAO 2008; Friedrich and Kassam 2009; Friedrich et al. 2009; Kassam et al. 2009, 2010; Friedrich et al. 2012).

\subsection{Permanent or Semi-permanent Organic Soil Cover}

In CA, crop residues - the principal element of permanent soil cover-must not be removed from the soil surface or burned. The residue is left on the soil surface to protect the topsoil enriched with organic matter from erosion. At the same time, fresh residues must be added to the soil when existing residues decompose. Burning 
not only increases mineralization rates which rapidly depletes nutrients and organic matter from the soil but also causes air pollution (Magdoff and Harold 2000). In CA, plants are either left in the field or killed, with their residues left in the field to decompose in situ. This practice is primarily aimed at protecting the enriched topsoil against chemical and physical weathering. Plant residues slow down the speed of falling raindrops, provide a barrier against strong winds and temperature, decrease surface evaporation, and improve water infiltration (Thierfelder and Wall 2009).

Cover crops/green manure crops are grown to increase or maintain soil fertility and productivity. They increase SOM content either by adding fresh plant residues to the soil or by reducing soil erosion. Legume cover crops can fix nitrogen from the atmosphere into the soil increasing $\mathrm{N}$ availability to crop plants. Cover crops are mowed or killed before or during soil preparation for the next economic crop. A gap of 1 or 2 weeks before planting the next crop is needed to allow some decomposition and reduction in allelopathic effects of the residues, and to minimize nitrogen immobilization (Miguel et al. 2011; Farooq and Nawaz 2014).

CA improves soil biodiversity, soil biological activity, water quality and soil aggregation, and increases soil carbon sequestration through maintenance of crop residues. By keeping residues on the surface and using cover crops, permanent soil cover is maintained during fallow periods as well as during crop growth phases. Giller et al. (2009) opined that the benefits of each principle need to be properly evaluated as trade-offs exist and some farmers have not adopted all of CA components. Retaining crop residues has positive and negative effects; researchers should develop strategies to enhance the positive effects (Kumar and Goh 2000).

\subsection{Minimal Soil Disturbance}

CA promotes minimal soil disturbance through no- or reduced tillage, careful management of residues and organic wastes, and a balanced use of chemical inputs; all aimed at decreasing soil erosion, water pollution and long-term dependence on external inputs, improving water quality and water-use efficiency, and minimizing greenhouse gas emissions by reducing the use of fossil fuels (Kumar and Goh 2000). Zero-tillage systems need minimal mechanical soil disturbance and permanent soil cover to achieve sufficient living and/or residual biomass to control soil erosion which ultimately improves water and soil conservation (Li et al. 2007). CA emphasizes the importance of soil as a living body, particularly the most active zone in the top $0-20 \mathrm{~cm}$, to sustain the quality of life on this planet; yet this zone is most vulnerable to degradation and erosion. Most environmental functions and services - essential to support terrestrial life on this planet-are concentrated in the macro-, micro-, and meso-flora and fauna, which live and interact in this zone. Human activities with regard to land management have the most immediate and potentially maximum impact in this zone (Hobbs et al. 2008). By protecting this fragile zone, the vitality, health, and sustainability of life on this planet may be ensured. 
A recent modeling analysis, for three sites with fine-textured soils and different crop rotations in North America (Conant et al. 2007), simulated zero tillage until equilibrium was reached and ran experimental models for 220 years thereafter. The model demonstrated a substantial decrease $(\sim 27 \%)$ in soil C content due to a shift to conventional tillage from zero tillage (Conant et al. 2007).

\subsection{Diversified Crop Rotations}

Crop rotations play a critical role in determining the success of crop production enterprises, but are most important in determining the success of crop production systems using conservation tillage. CA addresses the problems of insect, pests, and diseases by integrating crop rotations, which help break the cycle that perpetuates crop diseases such as wheat rust and pest infestations (Witmer et al. 2003), resulting in higher yield. A well-planned systematic crop rotation helps farmers to avoid many problems linked with conservation tillage, such as increased soil compaction, plant diseases, perennial weeds, and slow early season growth (Tarkalson et al. 2006).

Continuous maize planting in a no-till system may cause several problems such as perennial weeds, leaf diseases, inoculum buildup in residues, and wetter and cooler soils at planting due to heavy maize residues (Fischer et al. 2002). These residues interfere with seed placement resulting in uneven stand establishment; while allelopathic effects from decomposing maize residues on young plants may slow the growth of maize early in the season (Fischer et al. 2002). In such situations, a maize-hay rotation - as an alternative to continuous maize - is gaining popularity on dairy farms in Pennsylvania. Many problems linked to continuous no-till maize may be eliminated in this rotation when the sod is killed in autumn. The residue level will be manageable, the flux of perennial weeds will be less, insect problems will be less, and the soil structure usually will be excellent resulting in higher yields. Inclusion of Sesbania in direct-seeded rice as a green manure intercrop and then knocking it down with broadleaf herbicide has been effective in suppressing weeds and improving soil fertility in rice-wheat cropping systems (Yadav 2004; Hobbs et al. 2008).

With systematic crop rotations, the benefits of CA can be achieved on soils or at locations where success is often difficult. Combining the timeliness and reduced-labor benefits of CA with advantages of higher yield and reduced inputs when associated with a better crop rotation significantly increased profit levels (Linden et al. 2000).

\subsection{Weed Control}

Weed control is considered a serious problem in CA systems and its success largely depends on effective weed control. Multiple tillage operations are required to control perennial weeds by reducing the energy reserves in different storage organs 
or roots of weeds (Todd and Derksen 1986; Fawcett 1987). Weed control in CA depends upon agronomic practices, herbicides, and level of tillage used (Lafond et al. 2009). In CA systems, small-seeded weed species are favored (Chauhan et al. 2006a; Farooq and Nawaz 2014), while dormant weed seeds present in the soil do not move to the soil surface (Cardina et al. 1991). In CA, crop residues are maintained on the soil surface that keeps the soil moist and cool, which increases the survival of germinated small weed seeds compared with conventional agriculture. In conventional tillage systems, weed seeds are buried in the soil, while in CA more weed seeds are left on the soil surface (Chauhan et al. 2006b), which are generally more susceptible to decay (Gallandt et al. 2004).

Chemical weed control is the most effective weed management option in CA; however, its effectiveness depends upon several factors including application of appropriate herbicides, time of application (postemergence vs. preemergence), and the amount of crop residue present on the soil surface. Crop residues directly affect weed germination and the bioavailability of herbicides such as trifluralin (Chauhan et al. 2006c). Residue retention strongly impacts weed emergence; several factors determine the extent of this influence including type and quantity of residue, nature of the residue, soil type, weather conditions, and prevailing weed flora (Buhler 1995; Chauhan et al. 2006d). Phenolics in the surface residue may reduce the weed infestation (Farooq et al. 2011b) in CA system. Nonetheless, the presence of plant residues may reduce the persistence and efficacy of soil-applied herbicides, which do not require incorporation into the soil and also intercept and bind the chemical before it reaches the soil surface (Potter et al. 2008).

The availability of transgenic crops with resistance to nonselective herbicides, such as glyphosate and glufosinate, can effectively control weed species while decreasing labor demands and repeated applications of herbicides (Cerdeira and Duke 2006). By using transgenic crops in CA, growers have boosted profitability by reducing labor expenses. The introduction of herbicide-tolerant transgenic crop varieties in CA systems provided effective weed control with substantial yield increases (Duke and Powles 2008). A new challenge to develop herbicide-resistant weed biotypes is threatening the use of herbicide-tolerant transgenic crops in CA systems (Farooq et al. 2011a; Heap 2014). Several weeds have developed resistance against herbicides. The first case was reported in 1970 in common groundsel (Senecio vulgaris L.), which developed triazine resistance (Ryan 1970). Worldwide, the number of herbicide-resistant weed biotypes has reached 432, which demands continued research to control the resistance and avoid the future spread of resistant weeds (Appleby 2005; Heap 2014).

Kirkegaard et al. (2014) opined that herbicide rotation, green/brown manures, and harvesting and destruction of weed seeds may help in weed management under CA systems. They further proposed to include strategic tillage as a component of integrated weed management approach where applicable and safe (with respect to erosion risk; Kirkegaard et al. 2014). This may help to reduce the incidences of development of herbicide-resistant weed biotypes. 


\subsection{The Role of Policy and Institutional Support}

$\mathrm{CA}$ is a multi-dimensional approach ensuring the sustainability of resource use and food security. Principally, CA offers resistance to the irrational use of natural reserves through good management practices such as minimal soil disturbance using optimized tillage operations, check on soil exposure to environmental calamities, and biodiversity maintenance through diversified crop rotations. With the everincreasing global population and urbanization reducing the amount of land under agriculture, food security has become a conundrum (Hobbs et al. 2008); the sustainable use of available resources is a key element of CA systems.

Adoption of CA is a paradigm shift requiring huge efforts and trade-offs at individual and institutional levels. In the long run, CA should be the ultimate solution to agricultural problems in small landholding farming communities (Derpsch 2003; Giller et al. 2009). CA research has progressed but adoption at the farmer level is a serious concern. Many factors hinder the uptake of CA by farmers and authorities: lack of proper information, poor knowledge dissemination, lack of demonstration, the need for long-term hard work, temporary decline in economic returns, hesitation, vague policies, lack of institutional support and natural disasters. Institutional support, innovative policy making, organizational collaboration, motivated think tanks, and government supervision are critical to develop a strong system for proliferation of CA (Kassam et al. 2012).

Policy making involves the realization of the available resources and serious approach to rethink the issue and options. Ecological, social, and political activism on the issue of natural resource depletion and sustainability has been ignited for 20-30 years at a global level. Understanding this problem provides the foundation for structural development and promotion of sustainable approaches along with an awareness campaign (Kassam et al. 2012). One important policy is "Save and Grow" coined by the Food and Agriculture Organization. It covers the idea of a two-way process of sustainable production and economical usage, which has simplified and clarified the theme of CA. Policy formation strengthens the expression, adoption, and promotion of this approach (FAO 2011b). Effective policies offer pragmatic solutions to a number of challenges (Kienzler et al. 2012) such as:

- Useful practices to improve food production under limited inputs and thus sustainable promotion of food production and the supply chain.

- Lowering the intensity of environmental damage through eco-friendly approaches.

- Economizing the production chain via improved cultural practices, judicious input use, and reduced exploitation of on-farm resources.

- Preserving ecological hierarchy by maintaining biodiversity and natural habitats.

- Offering a wide range of adjustments, adaptations, and rehabilitation after frequent natural and secondary disasters.

Plenty of evidence on the serious concerns, issues, and threats necessitating the adoption of CA are available (Foresight 2011); however, intensified production is still possible under a conservation regime with benefits including lower capital costs, reduced inputs, flexibility in terms of adaptation, aggrandized ecosystem ef- 
ficiency, and environmental protection. In some parts of the world, conservation tillage has been termed under transformed tillage packages like zero tillage, reduced tillage, minimum tillage, etc.

Institutions are the main hubs for information gathering, knowledge sharing, and technology transfer. The role of institutional development in agriculture is significant. Linkage between research organizations, educational institutes, and extension wings must be very strong to launch any technology. Considerable work is being undertaken on the adoption of CA on national and international fronts. Governments are sensing the vitality of the system and reinforcing the approach through multi-actions. In developed countries, the scientific community is leading the task by innovating and modifying the steps for sustainability. Strict implication of the rules and regulations has confirmed the success of CA in different cases.

Authorities are sensing their responsibilities, and public sector movements regarding CA adoption are flourishing. Different institutions support farming communities to trial subsidized conservation packages. Incentives and visual economic profitability help to promote adoption and reduce farming community concerns (Kassam et al. 2012). Adoption of zero tillage in the rice-wheat cropping system in the Indo-Gangetic Plains is a successful example of CA adoption in the developing world. It is the result of consistent efforts by global institutions and organizations in collaboration with local governments and NGOs. Similarly, successful progress is being made in Central Asia, Africa, and other regions. Conservation approaches are not only becoming popular but also being adopted at the farmer level, which could improve with further institutional support and the right policy making in the future.

\subsection{Conclusion}

CA is a complex suite of technologies, including wise soil manipulation, retention of crop residues as soil cover, planned and diversified crop sequences, and effective weed management, for eco-friendly sustainable crop production. CA has proved beneficial in terms of yield, income, sustainability of land use, ease of farming, and the timeliness of ecosystem services and cropping practices. CA systems are being increasingly adopted worldwide; however, in some countries, its adoption is either slow or nonexistent. Sustained governmental policies and institutional support may play a key role in the promotion of CA through the provision of required services for farming communities and certain incentives. On-farm participatory research and demonstration trials may help accelerate the adoption of CA. The development and introduction of herbicide-tolerant transgenic crops resulted in the rapid spread of CA systems; however, the development of herbicide-resistant weed biotypes is posing a new threat. This invites attention of researchers to develop economically viable innovative alternative tools to prevent and manage herbicide-resistance development in weeds and weed management strategies. The use of Sesbania in directseeded rice as a manure intercrop and then using that as mulch with the application of broadleaf killer herbicide is a good option for weed and fertility management. 
Developing crop genotypes with strong allelopathic potential against associated weeds is another option in this regard.

\section{References}

Appleby AP (2005) A history of weed control in the United States and Canada a sequel. Weed Sci 53:762-768

Baker CJ, Saxton KE, Ritchie WR (2002) No-tillage seeding: science and practice, 2nd edn. CAB, Oxford

Barret DWA, Wiles TL, Barker MR (1972) Spray-seed with the bipyridyls in Western Australia. In: Proceedings no-tillage systems symposium, Columbus, 21-22 Feb 1972, pp 83-92

Bäumer K (1970) First experiences with direct drilling in Germany. Neth J Agric Sci 18:283-292

Boisgontier D, Bartholomy P, Lescar L (1994) Feasibility of minimum tillage practices in France. In: Proceedings of the EC-Workshop-I-, Giessen, 27-28 June, 1994, Experience with the applicability of no-tillage crop production in the West-European countries, Wissenschaftlicher Fachverlag, Giessen, pp 81-91

Borges G de O (1993) Resumo histórico do plantio direto no Brasil. In: EMBRAPA, Centro Nacional de Pesquisa de Trigo (Passo Fundo, RS). Plantio direto no Brasil. EMBRAPA-CNPT/ Fundacep Fecotrigo/Fundação ABC/Aldeia Norte, pp 13-17

Buhler DD (1995) Influence of tillage systems on weed population dynamics and management in corn and soybean in the central USA. Crop Sci 35:1247-1258

Cannel RQ, Hawes JD (1994) Trends in tillage practices in relation to sustainable crop production with special reference to temperate climates. Soil Till Res 30:245-282

Cardina J, Regnier E, Harrison K (1991) Long-term tillage effects on seed banks in three Ohio soils. Weed Sci 39:186-194

Cerdeira AL, Duke SO (2006) The current status and environmental impacts of glyphosate resistant crops: a review. J Environ Qual 35:1633-1658

Chauhan BS, Gill GS, Preston C (2006a) Seedling recruitment pattern and depth of recruitment of 10 weed species in minimum tillage and no-till seeding systems. Weed Sci 54:658-668

Chauhan BS, Gill GS, Preston C (2006b) Influence of tillage systems on vertical distribution, seedling recruitment and persistence of rigid ryegrass (Lolium rigidum). Weed Sci 54:669-676

Chauhan BS, Gill GS, Preston C (2006c) Tillage systems affect trifluralin bio-availability in soil. Weed Sci 54:941-947

Chauhan BS, Gill GS, Preston C (2006d) Tillage system effects on weed ecology, herbicide activity and persistence: a review. Aust J Exp Agric 46:1557-1570

Colmenero MR, Bienes R, Eldridge DJ, Marques MJ (2013) Vegetation cover reduces erosion and enhances soil organic carbon in a vineyard in the central Spain. Soil Till Res 104:153-160

Conant RT, Easter M, Paustian K, Swan A, Williams S (2007) Impacts of periodic tillage on soil C stocks: a synthesis. Soil Till Res 95:1-10

Derpsch R (2003) Conservation tillage, no-tillage and related technologies. In: Luis GT, José B, Armando MV, Antonio HC (eds) Conservation agriculture: environment, farmers experiences, innovations, socio-economy, policy. Springer Netherlands, pp 181-190

Derpsch R (2007) Historical review of no- tillage cultivation of crops. http://www.rolf-derpsch. com/notill.htm\#1\#1. Accessed 19 May 2014

Derpsch R, Friedrich T (2009) Development and current status of no-till adoption in the world. In: Proceedings on CD, 18th triennial conference of the International Soil Tillage Research Organization (ISTRO), Izmir, Turkey, 15-19 June 2009

Dill GM (2005) Glyphosate-resistant crops: history, status and future. Pest Manage Sci 61:219-224

Dixon J, Gulliver A, Gibbon D (2001) Farming systems and poverty: improving farmers' livelihoods in a changing world. FAO and World Bank, Rome 
Duke SO, Powles SB (2008) Glyphosate: a once-in-a-century herbicide. Pest Manage Sci 64:319-325

Dumanski J, Peiretti R, Benetis J, McGarry D, Pieri C (2006) The paradigm of conservation tillage. In: Proceedings of world association of soil and water conservation, pp 58-64

FAO (2006) Agriculture and consumer protection department. Rome, Italy. http://www.fao.org/ag/ magazine/0110sp.htm. Accessed 18 May 2014

FAO (2008) Investing in sustainable crop intensification: the case for soil health. Report of the international technical workshop, FAO, Rome, July. Integrated crop management, vol 6. FAO, Rome. http://www.fao.org/ag/ca/. Accessed 18 May 2014

FAO (2011a) CA adoption worldwide, FAO-CA website. http://www.fao.org/ag/ca/6c.html. Accessed 11 April 2014

FAO (2011b) Save and grow: a policymaker's guide to the sustainable intensification of smallholder crop production. FAO, Rome

Farooq M, Nawaz A (2014) Weed dynamics and productivity of wheat in conventional and conservation rice-based cropping systems. Soil Till Res 141:1-9

Farooq M, Flower K, Jabran K, Wahid A, Siddique KHM (2011a) Crop yield and weed management in rainfed conservation agriculture. Soil Till Res 117:172-183

Farooq M, Jabran K, Cheema ZA, Wahid A, Siddique KHM (2011b) The role of allelopathy in agricultural pest management. Pest Manage Sci 67:494-506

Faulkner EH (1943) Plowman's folly. Michael Joseph, London

Fawcett RS (1987) Overview of paste management for conservation tillage systems. In: Logan TJ, Davidson JM, Baker L, Overcash MR (eds) Effects of conservation tillage on groundwater quality: nitrtes and pesticides. Lewis, Chelsea, pp 19-37

Fischer RA, Santiveri F, Vidal IR (2002) Crop rotation, tillage and crop residue management for wheat and maize in the sub-humid tropical highlands. II maize and system performance. Field Crops Res 79:123-137

Foresight (2011) The future of food and farming. The Government Office for Science, London

Fraley RT, Stephen GR, Robert BH, Patricia RS, Jeffery SF, Steven PA, Michael LB, Leslie AB, Cynthia LF, Joyce SF, Gerald RG, Sarah BG, Nancy LH, Sherry CW (1983) Expression of bacterial genes in plant cells. Proc Natl Acad Sci U S A 80:4803-4807

Friedrich T, Kassam AH (2009) Adoption of conservation agriculture technologies: constraints and opportunities. In: Proceedings of the IV world congress on conservation agriculture, ICAR, New Delhi, India, 4-7 Feb 2009

Friedrich T, Kassam AH, Shaxson F (2009) Conservation agriculture. In: Agriculture for developing countries. Science and Technology Options Assessment (STOA) Project, European technology assessment group, Karlsruhe, Germany

Friedrich T, Derpsch R, Kassam AH (2012) Global overview of the spread of conservation agriculture. Field Actions Sci Rep 6:1-7

Fukuoka M (1975) One straw revolution, Rodale, Tokyo, p 138

Gallandt ER, Fuerst EP, Kennedy AC (2004) Effect of tillage, fungicide seed treatments and soil fumigation on seed bank dynamics of wild oat (Avena fatua). Weed Sci 52:597-604

Giller KE, Witter E, Corbllels M, Tittonell P (2009) Conservation agriculture and smallholder farming in Africa: the heritics view. Field Crop Res 114:23-34

Giráldez JV, González P (1994) No-tillage in clay soils under Mediterranean climate: physical aspects. In: Proceedings of the EC-workshop-I-, Giessen, 27-28 June 1994, Experience with the applicability of no-tillage crop production in the West-European countries, Wissenschaftlicher Fachverlag, Giessen, 1994, pp 111-117

Govaerts B, Verhulst N, Castellanos-Navarrete A, Sayre KD, Dixon J, Dendooven L (2009) Conservation agriculture and soil carbon sequestration; between myth and farmer reality. Crit Rev Plant Sci 28:97-122

Greenland DJ (1975) Bringing the green revolution to the shifting cultivators. Science 190:841844

Haggblade S, Tembo G (2003) Conservation farming in Zambia EPTD. Discussion Paper No. 108, International Food Policy Research Institute, Washington 
Hanks J, Martin SW (2007) Economic analysis of cotton conservation tillage practices in the Mississippi Delta. J Cotton Sci 11:75-78

Harrington LW (2008) A brief history of conservation agriculture in Latin America, South Asia and Sub-Saharan Africa. PACA, 1st Floor, NASC Complex, DPS Marg, Pusa, New Delhi-110 012, India

Heap I (2014) The international survey of herbicide resistant weeds. http://www.weedscience. com. Accessed 18 May 2014

Hillel D (1991) Out of the earth: civilization and the life of the oil. Free, New York

Hillel D (1998) Environmental soil physics. Academic, San Diego

Hobbs PR, Gupta RK (2004) Problems and challenges of no-till farming for the rice-wheat systems of the Indo-Gangetic Plains in South Asia. In: Lal R, Hobbs P, Uphoff N, Hansen DO (eds) Sustainable agriculture and the rice-wheat system. Ohio State University/Marcel Dekker, Columbus, pp 101-119

Hobbs RP, Sayre K, Gupta R (2008) The role of conservation agriculture in sustainable agriculture. Phil Trans R Soc B 363:543-555

Holland JM (2004) The environmental consequences of adopting conservation tillage in Europe: reviewing the evidence. Agric Ecosyst Environ 103:1-25

Kassam AH, Friedrich T, Shaxson F, Pretty J (2009) The spread of conservation agriculture: justification, sustainability and uptake. Int J Agric Sustain 7:1-29

Kassam AH, Friedrich T, Derpsch R (2010) Conservation agriculture in the 21st century: a paradigm of sustainable agriculture. In: Proceedings of the European Congress on conservation agriculture, Madrid, October 2010

Kassam A, Friedrich T, Derpsch R, Lahmar R, Mrabet R, Basch G, González-Sánchez E, Serraj R (2012) Conservation agriculture in the dry Mediterranean climate. Field Crops Res 132:7-17

Kern JS, Johnson MG (1993) Conservation tillage impacts on national soil and atmospheric carbon levels. Soil Sci Soc Am J 57:200-210

Kienzler KM, Lamers JPA, McDonald A, Mirzabaev A, Ibragimov N, Egamberdiev O, Ruzibaev E, Akramkhanov A (2012) Conservation agriculture in Central Asia - what do we know and where do we go from here? Field Crops Res 132:95-105

Kirkegaard JA, Conyers MK, Hunta JR, Kirkby CA, Watt M, Rebetzke GJ (2014) Sense and nonsense in conservation agriculture: principles, pragmatism and productivity in Australian mixed farming systems. Agric Ecosys Environ 187:133-145

Kumar K, Goh KM (2000) Crop residues and management practices: effects on soil quality, soil nitrogen dynamics, crop yield and nitrogen recovery. Adv Agron 68:198-279

Lafond GP, McConkey BG, Stumborg M (2009) Conservation tillage models for small scale farming: linking the Canadian experience to the small farms of Inner Mongolia Autonomous Region in China. Soil Till Res 104:150-155

Lal R (1976) No tillage effects on soil properties under different crops in western Nigeria. Soil Sci Soc Am Proc 40:762-768

Lal R (2001) Managing world soils for food security and environmental quality. Adv Agron $74: 155-192$

Li H, Gao H, Wu H, Li W, Wang X, He J (2007) Effects of 15 years of conservation tillage on soil structure and productivity of wheat cultivation in northern China. Aust J Soil Res 45:344-350

Linden DR, Clapp CE, Dowdy RH (2000) Long term grain and stover yields as a function of tillage and residue removal in east central Minnesota. Soil Till Res 56:167-174

Lindwall CW, Sonntag B (2010) Landscape transformed: the history of conservation tillage and direct seeding, knowledge impact in society. University of Saskatchewan, Saskatoon, Saskatchewan S7 N 5B8, Canada

Magdoff F, Harold VE (2000) Building soils for better crops. 2nd edn. Sustainable Agriculture, Burlington

Marongwe LS, Kwazira K, Jenrich M, Thierfelder C, Kassam A, Friedrich T (2011) An African success: the case of conservation agriculture in Zimbabwe. Int J Agric Sustain 9:153-161

Meena MS, Singh KM, Singh SS (2010) Conservation agriculture: adoption strategies. Agric Ext Rev 22:20-24 
Miguel AF, Peñalva M, Calegari A, Derpsch R, McDonald, MJ (2011) Green manure/cover crops and crop rotation in conservation agriculture on small farms. Plant Production and Protection Division, FAO, Rome

Montgomery DR (2007) Soil erosion and agricultural sustainability. Proc Natl Acad Sci U S A 104:13268-13272

Paarlberg RL (2001) The politics of precaution: genetically modified crops in developing countries. Johns Hopkins University Press, Balitmore

Perszewski R (2005) Ideas leading to no-till's second revolution. http://www.no-tillfarmer.com/ pages/Feature-Articles---Ideas-Leading-To-No-Tills-Second-Revolution.php. Accessed 2 June 2014

Potter TL, Truman CC, Strickland TC, Bosch DD, Webster TM (2008) Herbicide incorporation by irrigation and tillage impact on runoff loss. J Environ Qual 37:839-847

Powles SB, Lorraine-Colwill DF, Dellow JJ, Preston C (1998) Evolved resistance to glyphosate in rigid ryegrass. Weed Sci 46:604-607

Putte AV, Govers G, Diels J, Gillijns K, Demuzere M (2010) Assessing the effect of soil tillage on crop growth: a meta-regression analysis on European crop yields under conservation agriculture. Eur J Agron 33:231-241

Reicosky DC, Saxton KE (2007) The benefits of no-tillage. In: Baker CJ, Saxton KE, Ritchie WR, Chamen WCT, Reicosky DC, Ribeiro MFS, Justice SE, Hobbs PR (eds) No-tillage seeding in conservation agriculture. 2nd edn. CABI, Wallingford, pp 11-20

Ryan GF (1970) Resistance of common groundsel to simazine and atrazine. Weed Sci 18:614-616

Sartori L, Peruzzi P (1994) The evolution of no-tillage in Italy: a review of the scientific literature. In: Proceedings of the EC-Workshop-I-, Giessen, 27-28 June, 1994, Experience with the applicability of no-tillage crop production in the West-European countries, Wissenschaftlicher Fachverlag, Giessen, 1994, pp 119-129

Serraj R, Siddique KHM (2012) Conservation agriculture in dry areas. Field Crops Res 132:1-6

Singh KM, Meena MS (2013) Economics of conservation agriculture: an overview. Munich Personal RePEc Archive, MPRA Paper No. 49381. http://mpra.ub.uni-muenchen.de/49381/. Accessed 19 May 2014

Tarkalson DD, Hergert GW, Cassman KG (2006) Long term effects of tillage on soil chemical properties and grain yields of a dryland winter wheat-sorghum/corn-fallow rotation in the Great Plains. Agron J 98:26-33

Thierfelder C, Wall PC (2009) Effects of conservation agriculture techniques on infiltration and soil water content in Zambia and Zimbabwe. Soil Till Res 105:217-227

Todd BC, Derksen DA (1986) Perennial weed control in wheat in western Canada. In: Slinkard AE, Fowler DB (ed) Wheat production in Canada - a review. University of Saskatchewan, Saskatoon, pp 391-404

West TO, Marland G (2002) A synthesis of carbon sequestration, carbon emissions, and net carbon flux in agriculture: comparing tillage practices in the United States. Agric Ecosyst Environ 91:217-232

Witmer JE, Hough-Goldstein JA, Pesek JD (2003) Ground-dwelling and foliar arthropods in four cropping systems ground-dwelling and foliar arthropods in four cropping systems. Environ Entomol 32:366-376

World Resources Institute (2000) People and ecosystems, the frayling web of life. World Resources Institute, United Nations Development Programme, World Bank, Washington, USA, p 36. http://www.wri.org/wr2000/pdf/summary.pdf. Accessed 14 May 2014

Yadav RL (2004) Enhancing efficiency of fertilizer N use in rice-wheat systems of Indo-Gangetic Plains by intercropping Sesbania aculeata in direct seeded upland rice for green manuring. Bioresour Technol 93:213-215 